\section{P-209症候性前立腺要胞に対する経直腸的超音波 ガイド下ドレナージおよびエタノール固定}

\section{芸術の森泌尿器科 1 )}

斎藤 誠一1)

【目的】症候性前立腺豊胞に対し、経直腸的超音波ガイド下にド レナージ拉びェタノール固定を行い、その効果について㛟討を 加之た。【対象と方法】対象は排尿障害を訴元、超音波検査にて 巨大な前立腺囊胞を指摘された 3 例（60、73、78歳）である。方 法は無麻䡃下経直腸的超音波ガイド下に穿刺およびドレナージを 行い、内容物の半量にあたる100\%エタノールを注入し、5分間固 定後廃液回收を 2 度行い、針を抜去した。内容物は細胞診拉よび 培養検査に提出した。治療前後の排尿状況をIPSS拉よび尿流量測 定にて検討し、再発の碓認をむこう 2 年間行った。結果】全例 IPSSの低下、maximum flow rateの150\%以上の改善がみられた。内 容物の練胞診、培盖検查はすべて㓌性であった。治療中は疼痛等 のトラブルもなく、また再発もみられなかった。【結論】症候性 前立腺菙胞に対寸る経道腸的超音波ガイド下ドレナージおよびエ タノール固定はminimum invasiveで有効な治療法と考えられた。 前立腺胞胞 経直腸的超音波 エタノール

\section{P-210 排尿中の尿道抵抗の時間的変化についての 考察}

生長会府中病院1)

西本 憲一1）米田 幸生 ${ }^{1)}$ 清田 敦彦1）

西川慶一郎1) 西尾 正一1)

目的】尿流曲線から排尿中の尿道抵抗の時間的変化を検討する。 【対象と方法】臨床において得られた種々の尿流曲線(UFM)から排 尿のシミュレーションを使い排尿圧(P)を計算し、P拉よび流量 $(\mathrm{Q})$ から尿道抵抗(TR)を計算した。Pとは内外尿道口間の全圧差と定義 した。結果】TRは時間経過とともに減少して最小となり再び増 加する群と单調减少する群に二大別できた。TRの構成要素は慣性 抵抗と摩擦抵抗と弾性抵抗であるが、排永の初期には慣性抵抗が、 中期には摩擦抵抗が、後期には弾性抵抗がTRの大部分を占めてい た。すなわち、排尿初期には尿を加速する抵抗が存在し、後半に は尿道の弾性抵抗によるTRの増加がある。一群の違いは弾性抵抗 の存在に由来するPとQの位相差に起因していた。一般的に弾性抵 抗の少ない尿道は排尿後半は低圧高流量で抵抗は小さくなり、抵 抗は単調減少する。最小値群では尿流量が最大となる時尿道抵抗 が最小となった。排尿のシミュレーションは尿流曲線のみから排 尿圧を推定できるため非侵襲的にPressure-flow studyを実行できる。 さらに尿道内の流量を直接駆動する排㲾圧を推定できるため㽷道 抵抗を計算できる利点を持つ。尿道抵抗は感覚的に理解しやすい 量であり、排尿中の尿道の状態を表現する量として適当と考えら れた。

尿道抵抗 排尿のシミュレーション 非侵慗的

\section{P-211 インフォームドコンセントおよび癌告知に 関するアンケート調查〜入院患者とその家 族を対象にした研究c}

\section{市立室蘭総合病院}

立木俈1) 佐藤 英次1) 宮尾則臣1)

我々は個々の患者およびその家族がインフォームドコンセントや 癌の告知に関してどのように考えているかを子女把握しておく目 的で、入院時に患者㧍よびその家族に質問紙によるアンケートを 行っている。これまでに患者535名、その家族460名より得られた [回答結果を集計した結果、1、病態や検査結果の詳しい説明は患 者の79\%、家族の91\%が希望していた。しかし説明を受けた上で 患者自身が治療法を選ぶことを希望するのは患者の14\%、家族の 23\%にとどまった。2、癌の告知を希望する患者は83\%であった。 これに対し癌の告知を容認する家族は64\%であったが、絶対容認 できないとする家族は $25 \%$ \%゙あった。特に患者が高齢であるほど その家族が告知に消極的になる傾向にあった。3、癌の告知は、 患者の $60 \%$ が家族よりも先にまず患者に知らせてほしいと考えて いたのに対し、家族は87\%がまず最初に家族に知らせてほしいと 考えて扔り、最初に患者に知らせてよいとする家族は12\%にとど まった。4、告知を希望する患者の70\%は、たとえ家族が告知に 反対であっても告知してほしいと考えていた。

インフォームドコンセント 質問紙

\section{P-212 相談泌尿器科}

\section{泌尿器科田宮医院 ${ }^{1 !}$}

田宮高宏 ${ }^{1)}$

目的）他の医療機関に往診し，主治医から依頼された患者を病室 で診察するばあいの，医師一医師関係，医師一患者関係拧よび診 療手順の技術について反省しておく． 对象）約 10 年間に，脳 神経外科病院 1, 内科系病院 304 病院に拀いて, 1，234名 の患者を診察した。結果) 患者の大部分は高秢者で, 男女比は 2：1である。相談の内容は尿閉や尿失禁についてがもっとも多 く, 次いで血尿など尿の性状に関する問題, 尿路のカテーテル管 理をめぐっての事などであった. 395 例では最初の診祭で「相 談」が終結した２２回目以降に終結したのは198例であった。 検査のため 147 例が当院を受診した.治療指針の結論を出して いないのに相談関係の途切れたケースが296例あった. 泌尿器 科手術の目的で転院となったのは59例であった。考案)この ようなばあい, CLIANTは患者ではなくてその主治医であり，泌 尿器科醫たる私はいわば主治医のスタッフとして患者と相対す る. また直ちには泌尿器科的な検査ができない.したがって「相 談」に拈るHUMAN RELATION と効率的な診察手順を考慮する 必要があった。

CONSULTATION UROLOGY DOCTOR-DOCTOR RELATION DOCTOR-PATIENT RELATION 